\title{
Optimization of compaction pressure on brick
}

\author{
Ade Indra $^{1 *}$,Edison Edison ${ }^{1}$, Hendri Nofrianto ${ }^{2}$ \\ ${ }^{1}$ Institut Teknologi Padang, Mechanical Engineering Department, Padang, Indonesia \\ ${ }^{2}$ Institut Teknologi Padang, Civil Engineering Department, Padang, Indonesia
}

\begin{abstract}
Bricks are one of the building materials that serves as a wall or anchoring the load. Therefore, it must be made according to the standards. In our previous observations, many found bricks were traditionally not quality, because the process of making bricks that are not right. Bricks are a class of ceramic materials that must be hard and should not be crushed when immersed in water. The method in this study focuses on optimizing compaction pressures, with printed pressures that are varied in MPa units. The results obtained as follows, in terms of mechanical properties of Compressive Strength increases with the addition of compaction pressure, an increase of $36 \%$ (brick becomes strong). In terms of physical properties of Density increased (porosity becomes smaller). For Suction rate down, this shows less water absorption. The results obtained in accordance with national and international quality standards.
\end{abstract}

\section{Introduction}

West Sumatera is located on the west coast of the island of Sumatera, which in recent years have often shaken by earthquakes with a high scale. The earthquake that occurred in 2005, 2007 and the last on 30 September 2009 with 7.9 on the Richter scale, many homes, offices, and other buildings damaged. Damage caused to the building is on the wall, made of clay brick. In building construction, clay bricks are used as a buffer to the existing load on it, such as the construction of houses and foundations. If the strength of the clay brick used is not the same with SNI and other standards, it will be very dangerous for the safety of people living in the building [1].

This should be our common concern, how to create and process quality clay brick accordance with SNI. From our observations on the clay brick home industry in the Payakumbuh West Sumatera, there are three weaknesses in the making, namely: 1) Material and composition used has not been qualified. 2) The compaction pressure of a clay brick process. 3) Firing temperature of the fuel of rice husk is very low $\left(600^{\circ} \mathrm{C}\right)$, should be $1000^{\circ} \mathrm{C}[1]$. To resolve this problem, further research is needed, so that the clay brick produced meets quality standards.

This research is a continuation of our earlier research team, focused on reviewing the compaction pressure, which is also a requirement to get the results of quality bricks.

\section{Materials and Methods}

Clay brick is one of the building materials, made of clay with or without impurities, is burned at high temperatures, and not destroyed soaked in water [2].

Composite bricks reinforced with fly ash is in the maximum addition of $50 \%$ fly ash. For the addition of over $50 \%$, the compressive strength of the bricks fell. While the physical characteristics of the bricks using fly ash is lighter, smaller water absorption, and more solid [3].

The clay consists of microscopic particles and submicroscopic shaped flat plate and mica particles, clay minerals, and other minerals are very fine with a size of $0.002 \mathrm{~mm}$. The use of clay for brick making, should note a few things: (a) meet the plasticity and cohesive, so it can be easily formed. Clay has a value of plastic, can cause the bricks to crack or break when burned, (b) clay must have the ability to dry high and shrinkage dry low (maximum 10\%), (c) not contain grains of chalk and gravel larger than $5 \mathrm{~mm}$, (d) sandy clay will produce brick better when compared with the use of pure clay.

Water is used to process the binding reaction material in the manufacture of bricks. Clay brick is made of clay with or without a mixture of other materials through the combustion process. Clay bricks baked at high temperatures, do not disintegrate when immersed in water, and has a small hole cross-sectional area of $15 \%$ of the area of the flat pieces.

The effect of firing time and temperature on compressive strength, water absorption, bending strength, weight loss, firing shrinkage and densities of clay brick were determined. For a given clay and method of manufacture, higher compressive and bending strengths, higher density and lower absorption are associated with higher firing temperatures. Increasing firing time only slightly altered the 
mechanical and physical properties of clay brick. However, firing temperature significantly affected the physical properties. The results suggested that firing temperature was the key factor to modulate the physical properties of bricks. However, the effect of firing time was not significant. The results obtained in this study can only be compared to the properties of bricks produced under similar conditions with similar raw materials [4].

Research bricks have been done to determine of compaction pressure, variation is $30 ; 60 ; 90 ; 120 ; 150$; $180 ; 210 ; 240$; and $270 \mathrm{kPa}$. The results obtained as follows, the mechanical properties: Compression Strength increases as the addition of compaction pressure of $35.75 \mathrm{~kg} / \mathrm{cm}^{2}$ become $45.80 \mathrm{~kg} / \mathrm{cm}^{2}$, an increase of $28 \%$ (brick becomes stronger). Judging from the physical properties: density increased from 2.06 $\mathrm{g} / \mathrm{cm} 3$ became $2.24 \mathrm{~g} / \mathrm{cm} 3$, an increase of $8.9 \%$ (porosity becomes smaller). For Suction rate dropped from $16.17 \mathrm{~g} / \mathrm{dm}^{2} / \mathrm{min}$ to $14.82 \mathrm{~g} / \mathrm{dm}^{2} / \mathrm{min}$, this indicates the water absorption becomes smaller [5]. Class of divisions brick based on compressive strength [6].

Table 1. Compressive strength and coefficient of variation for solid brick for wall pair (SNI 15-2094-2000)

\begin{tabular}{ccc} 
Class & $\begin{array}{c}\text { Minimum average } \\
\text { compressive strength } \\
\text { of brick } \\
\mathbf{K g} / \mathbf{c m}^{2} \text { (MPa) }\end{array}$ & $\begin{array}{c}\text { Variation } \\
\text { coefficient of the } \\
\text { average } \\
\text { compressive } \\
\text { strength of the } \\
\text { tested (\%) }\end{array}$ \\
\hline 50 & $50(5)$ & 22 \\
100 & $100(10)$ & 15 \\
150 & $150(15)$ & 15 \\
\hline
\end{tabular}

The size and tolerance of bricks for the wall pair [6], can be seen in Table 2.

Table 2. Size of brick (SNI 15-2094-2000)

Unit in $\mathrm{mm}$

\begin{tabular}{cccc}
\hline Module & High & Wide & Long \\
\hline M-5a & $65 \pm 2$ & $90 \pm 2$ & $190 \pm 4$ \\
M-5b & $65 \pm 2$ & $100 \pm 2$ & $190 \pm 4$ \\
M-6a & $52 \pm 3$ & $110 \pm 2$ & $230 \pm 5$ \\
M-6b & $55 \pm 3$ & $110 \pm 2$ & $230 \pm 5$ \\
M-6c & $70 \pm 3$ & $110 \pm 2$ & $230 \pm 5$ \\
M-6d & $80 \pm 3$ & $110 \pm 2$ & $230 \pm 5$ \\
\hline
\end{tabular}

One of the properties of brick that affect to construction work is water absorption. Water absorption should be controlled, to prevent the loss of water from the mortar. The maximum water absorption for bricks is $20 \mathrm{~g} / \mathrm{dm}^{2} / \mathrm{min}$, when the suction rate of brick value greater than $20 \mathrm{~g} / \mathrm{dm}^{2} / \mathrm{min}$, then the bricks need to be soaked in water before paired to the wall [7].

Theoretical density of the single phase can be determined from the literature, while the actual density of single phase or composites tested using Archimedes theory [8]. Methods and stages of research as follows:
Intake sample material to make brick is home industry Koto Panjang, Lamposi Tigo Nagori, Payakumbuh. The material consists of clay mixed with white sand with a composition of 2:1 (as matrix), while for reinforcing materials used silica RHA, which is the result of burning rice husk waste.

\section{Manufacture of test samples}

The Molding process of brick with size samples test of $5 \times 5 \times 5 \mathrm{~cm}$ with variation compaction pressure: $0.5 ; 0.7$; $0.9 ; 1.1 ; 1.3$; and $1.5 \mathrm{MPa}$. Further drying is done without direct sunlight. The combustion process carried out test samples with methods that have been developed in previous studies, with rice husk fuel. The process of making the test sample as shown in Figure 1.
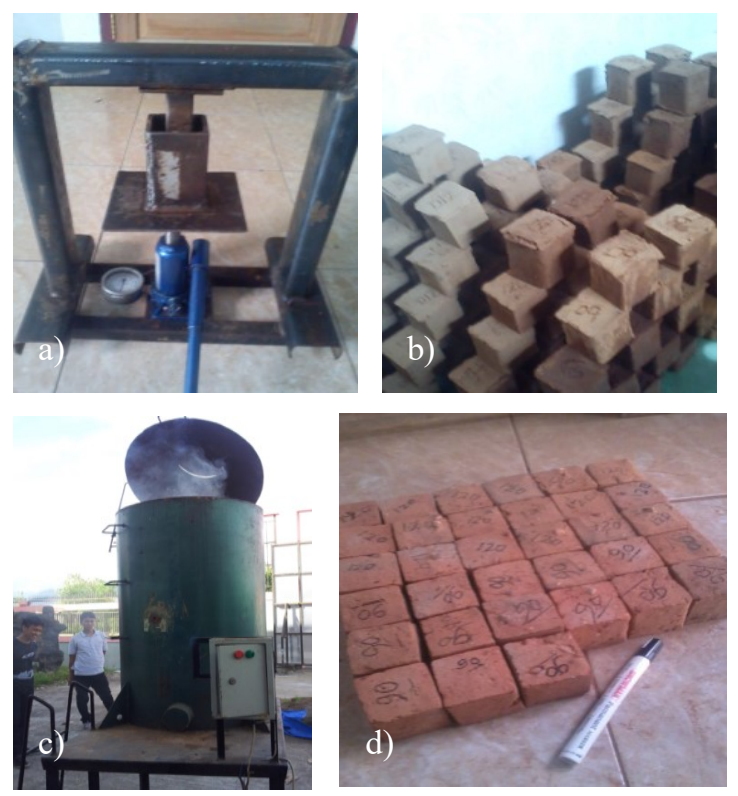

Fig 1. the manufacturing process of the test sample: a) mold, b) green body, c) the burning process, d) sample test

\section{Results and Discussion}

From the research that includes making samples, burn, making of the specimen, and the test can be described as follows.

\subsection{Firing Process}

Firing processes refer to our previous study, using a furnace with a temperature setting of approximately 930 ${ }^{\circ} \mathrm{C}$, as shown in the Table 3 and Figure 2.

Extra air in the burning process, the temperature is increased significantly when compared with no addition of air. Rising temperatures expected because more complete combustion, which is a proper balance between fuel with air. This occurs in speed of air blown of $0.25 \mathrm{~m} / \mathrm{s} ; 0.5 \mathrm{~m} / \mathrm{s}$ and $0.75 \mathrm{~m} / \mathrm{s}$ (burning temperature qualify for clay materials) 
Table 3. Burning Temperature

\begin{tabular}{ccc}
\hline $\begin{array}{c}\text { Speed of air } \\
\text { blown (m/s) }\end{array}$ & $\begin{array}{c}\text { Max temperature } \\
\left(\mathbf{(}^{\mathbf{0}} \mathbf{C}\right)\end{array}$ \\
\hline 0 & 498,3 & \\
0,25 & $934,7 \longleftarrow$ Temperatures \\
0,50 & 964,3 & used \\
0,75 & 1.035 & \\
1,00 & 824,0 & \\
\hline
\end{tabular}
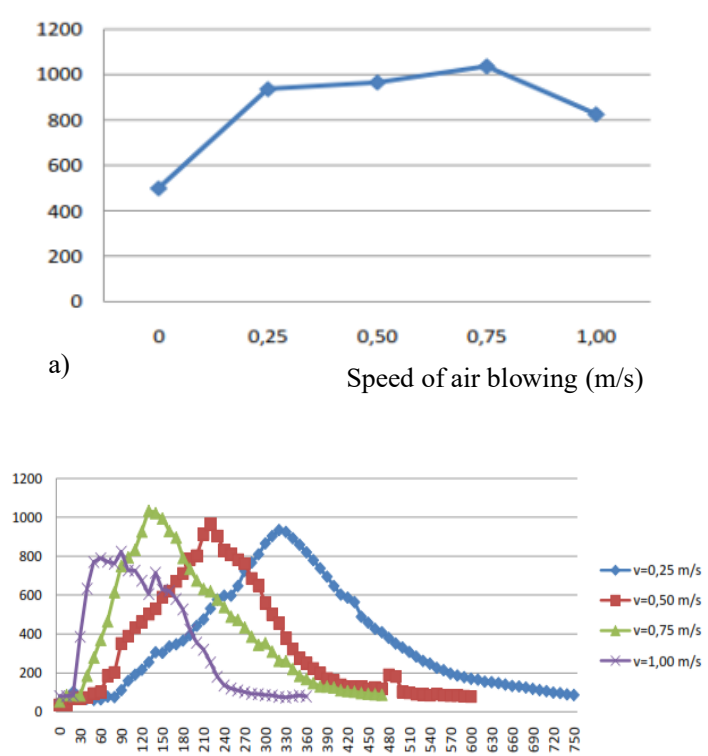

b) The burning time

Fig 2. a) Variation of burning temperature with speed of air blown. b) Variation of firing temperature with burning time

\subsection{Density}

The density test is shown in the following scheme in figure 3 .

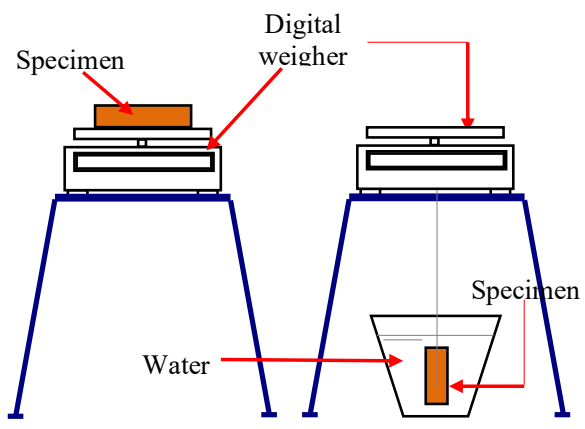

Fig. 3. scheme of density test

The test results density as shown in Table 4 and Figure 4. higher compaction pressure, the higher the density. but has not increased significantly to the increase in relative density, the highest value is $90.49 \%$. It also relates to the value of water absorption remains high (see Table 6). it is quite common for ceramic products with pores large enough
Table 4. density test results

\begin{tabular}{ccc}
\hline $\begin{array}{c}\text { Compaction } \\
\text { pressure } \\
\text { (MPa) }\end{array}$ & $\begin{array}{c}\text { Density } \\
\text { (gr/cm3) }\end{array}$ & $\begin{array}{c}\text { Relative } \\
\text { Density (\%) }\end{array}$ \\
\hline 0.5 & 2.29 & 88.68 \\
0.7 & 2.30 & 88.98 \\
0.9 & 2.30 & 89.11 \\
1.1 & 2.30 & 89.22 \\
1.3 & 2.31 & 89.63 \\
1.5 & 2.33 & 90.49 \\
\hline
\end{tabular}
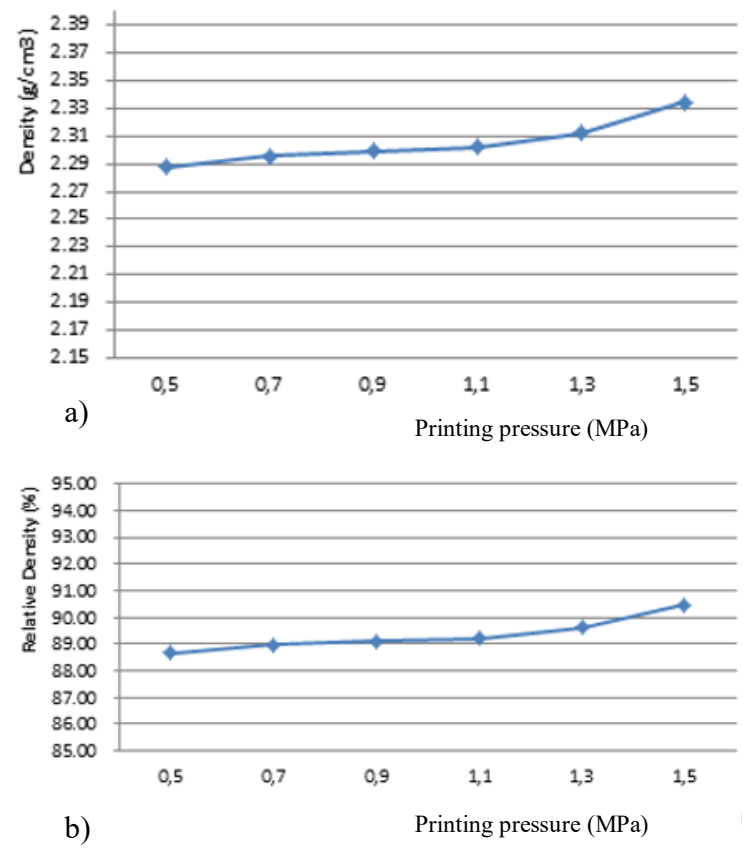

Fig 4. a) Variation of density with compaction pressure, b) Variation of relative density with compaction pressure

\subsection{Suction Rate and Water Absorption}

The suction rate test is shown in the following scheme in figure 5

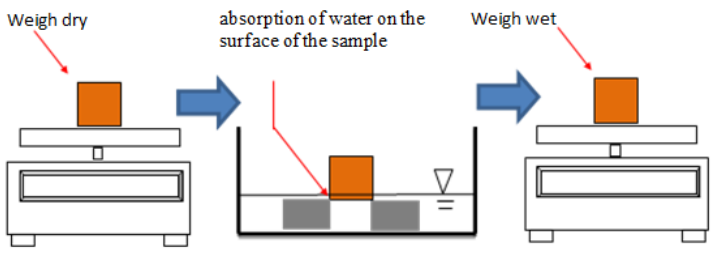

Fig 5. Scheme of suction rate test

From the test data suction rate, the suction rate on average has been under $20 \mathrm{~g} / \mathrm{dm}^{2} / \mathrm{min}$, the soaking time 3 and 4 minutes as a data table 5 , meaning that the brick before use should be soaked in water approximately 3 minutes, this also supported by water absorption test data (Figure 7) where most of the test samples had a water absorption above the specified limit of $20 \%$.

From figure 6 it can be seen that there is a significant relationship between suction rate by compaction pressure, the higher the compaction 
pressure then lower the suction rate, it is suspected that the density of the composite material when molded, so that the occurrence of contact tangentially between the granular material after molded process [8]. Water absorption as shown in Table 6 Figure 7, that there is no significant relationship between the water absorption by the compaction pressure variation, is suspected to be the micro cracks in the test specimen which is probably caused by the quality of the composite material.

Table 5. Suction rate test results

\begin{tabular}{ccc}
\hline $\begin{array}{c}\text { Compaction } \\
\text { pressure } \\
(\mathbf{M P a})\end{array}$ & \multicolumn{2}{c}{$\begin{array}{c}\text { Average Suction Rate } \\
\left(\mathbf{g} / \mathbf{d m}^{\mathbf{2}} / \mathbf{m i n}\right)\end{array}$} \\
\cline { 2 - 3 } & $\mathbf{3} \mathbf{~ m i n}$ & $\mathbf{4} \mathbf{~ m i n}$ \\
\hline 0.5 & 21.98 & 13.23 \\
0.7 & 15.01 & 16.98 \\
0.9 & 13.30 & 7.73 \\
1.1 & 10.56 & 8.85 \\
1.3 & 12.34 & 14.06 \\
1.5 & 11.26 & 11.63 \\
\hline
\end{tabular}

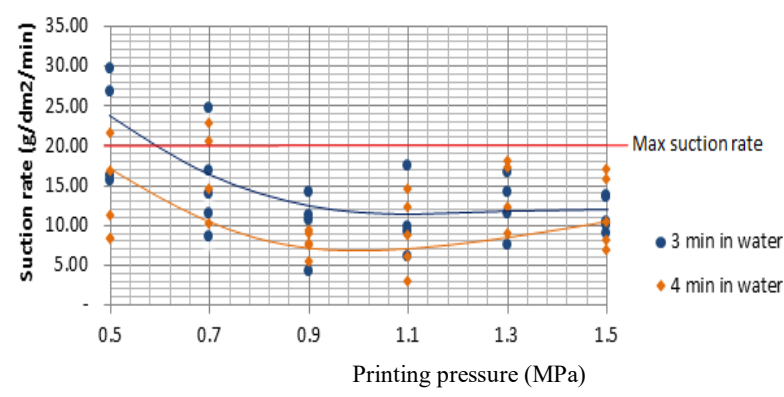

Fig 6. The variation of Suction rate with compaction pressure

Table 6. Water absorption test results

\begin{tabular}{cc}
\hline $\begin{array}{c}\text { Compaction } \\
\text { pressure } \\
\text { (Mpa) }\end{array}$ & $\begin{array}{c}\text { Average } \\
\text { Water Absorption (\%) }\end{array}$ \\
\hline 0.5 & 23.59 \\
0.7 & 23.90 \\
0.9 & 23.90 \\
1.1 & 23.51 \\
1.3 & 23.60 \\
1.5 & 23.17 \\
\hline
\end{tabular}

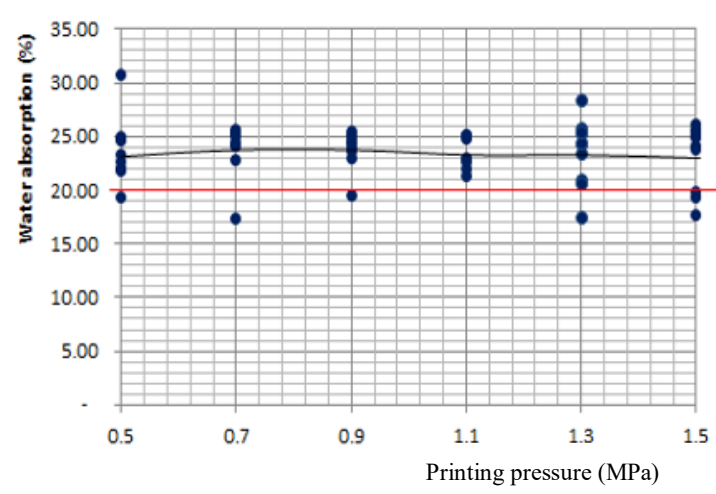

Fig 7. Variation of water absorption with compaction pressure
In the use and specification of clay bricks water absorption porosity is often taken as a guide for the prediction of frost resistance, in that bricks of high strength and low porosity have generally proved to be frost resistant in practice. However, it has been shown that frost damage is a result of complex patterns of freezing of pore water, and porosity alone is not the determining parameter of frost resistance. Thus several types of relatively porous clay bricks (notably some hand-made bricks) [9].

The capillary suction properties of masonry materials are relevant in respect of both construction practice and weathering performance. During construction wet trade practices rely upon the suction of masonry materials to encourage bonding between mortar or plaster and brickwork or block work. In brick or block laying excessive suction causes rapid removal of water from the soft mortar and can, in principle, result in incomplete hydration and a weak or porous hardened mortar. Similar considerations apply in the application of the renders or plasters to brick or block substrates [9].

\subsection{Compressive Strength}

The compressive strength test is shown in the following scheme in figure 8 .

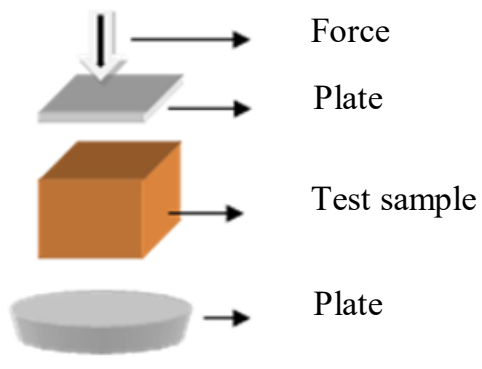

Fig. 8. Scheme of compressive strength test

Compressive strength is one of the parameters used to determine the strength and ability of a material to accept the load until the material is cracked and broken. The compressive strength test is performed using Universal Testing Machine. The cross-sectional area of the tested sample is the plane in direct contact with the load. The test process can be seen in figure 9 , test results can be seen in table 7 and Figure 10
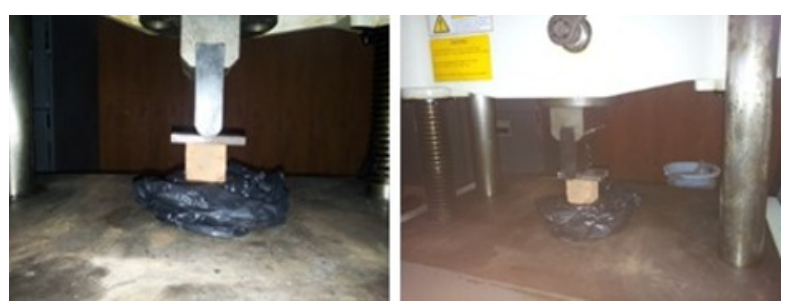

Fig. 9. Process of compressive strength test 
Table 7. Compressive strength test results

\begin{tabular}{ccc}
\hline No & $\begin{array}{c}\text { Compaction } \\
\text { pressure (Mpa) }\end{array}$ & $\begin{array}{c}\text { Compressive } \\
\text { Strength (kg/cm2) }\end{array}$ \\
\hline 1 & 0.5 & 47.07 \\
2 & 0.7 & 46.20 \\
3 & 0.9 & 64.24 \\
4 & 1.1 & 63.02 \\
5 & 1.3 & 61.43 \\
6 & 1.5 & 59.48 \\
\hline
\end{tabular}

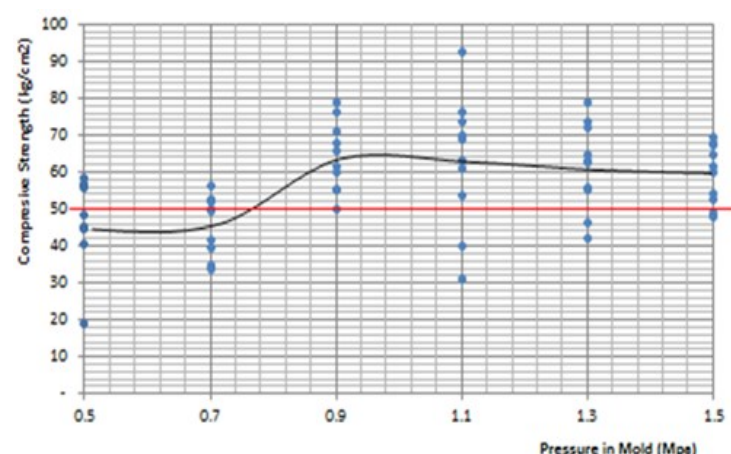

Fig. 10. Variation of compressive strength with compaction pressure

From the test results data in Table 7 and Figure 10, the average value of compressive strength test increases with the addition of pressure during printing. Seen from the garfic, the print pressure of 0.5 and 0.7 of the compressive strength value is still below the minimum standard of SNI 15-2094-2000, indicated by a red horizontal line. At print pressures of 0.9 to 1.5, indicating a good compressive strength and above the minimum standard required by SNI 15-2094-2000 (as shown in the Table 1). The results concluded that 0.9 or 1.0 $\mathrm{MPa}$ print pressure yielded an optimum compressive strength value of $64.24 \mathrm{~kg} / \mathrm{cm} 2$.

\section{Conclusions}

From the results of discussion, the optimum compaction pressure is between 0.9 to $1 \mathrm{MPa}$. The average suction rate has been below $20 \mathrm{~g} / \mathrm{dm}^{2} / \mathrm{min}$, it is recommended that the bricks should be immersed in water for 3 minutes before use in construction.

\section{Acknowledgments}

Given to:

- Directorate General of Higher Education, the Ministry of Ristek and Dikti, the Republic of Indonesia, which has funded research in Hibah Bersaing scheme, budget year 2016

- Kopertis Region X, which has helped the administration in this research

- LP2M, Instiut Teknologi Padang, which has helped the administration in this research

- Mechanical Engineering Laboratory, Institut Teknologi Padang, which has helped the facility and equipment in this research

\section{References}

1. A. Indra, N. Nurzal, H. Nofrianto. Improvement of Mechanical Properties of Composites Clay / Silica RHA for Quality Red Brick Applications, Proceeding of national conference mechanical engineering XIII, Universitas Indonesia (2014).

2. Y. Romadhona, Effect of increase Incinerator Ash on brick quality with clay from Temanggung district, Civil Engineering UNS

3. Muhardi, Characteristics of Clay Bricks improvement with addition of fly ash, Journal of Civil Engineering, 7(2), 165-179 (2007)

4. S. Karaman, S. Ersahin, H. Gunal, Firing temperature and firing time influence on mechanical end physical properties of clay bricks. Journal of scientific and industrial research. Vol. 65. 153-159 (2006)

5. A. Indra, N. Nurzal, H. Nofrianto, Optimizing compaction pressure on the composite clay/silica RHA for application bricks SNI quality, Proceeding of National Conference SPI-ITP (2014)

6. SNI 15-2094-2000. Solid brick for wall couple. ICS 91.100.20 (2000)

7. PEDC. Material Engineering, Bandung. (1983)

8. M. Barsoum, Fundamental of ceramics, (The Mc Graw Hill Companies Inc, US, (1997)

9. M.A. Wilson, M.A. Carter, W.D. Hoff. British Standart and RILEM water absorbtion test, Journal of Material and structures, 32, 571-578, (1999) 